\title{
Bilingual Color Learning Application as Alternative Color Learning for Preschool Student
}

\author{
https://doi.org/10.3991/ijim.v16i05.28319 \\ Wirawan Istiono ${ }^{(凶)}$ \\ Universitas Multimedia Nusantara, Tangerang, Indonesia \\ wirawan.istiono@umn.ac.id
}

\begin{abstract}
Color recognition skills for early childhood are very important as a basis for starting other learning, by recognizing colors a child will get the benefits of creative development, development of sensory abilities and other positive benefits. Based on the results of observations that has been done in the kindergarten school that locate in Tangerang, Indonesia, it was found that most children were still often confused or had difficulty distinguishing colors through conventional teaching. In this research, a color recognition application was built in two languages, which aims to help students to recognize color faster. Testing will be carried out using the pretest and posttest methods with the "paired sample $t$ test" method to measure the level of student development before and after using the application, user acceptance testing will also be carried out using UAT to measure the level of user acceptance of the application that had been made. From these evaluation, it was found that the results of the development were quite good with the t-stat results of 8.69 and the user acceptance test results of $86.72 \%$.
\end{abstract}

Keywords—bilingual application, color learning, alternative learning, preschool student

\section{$1 \quad$ Introduction}

The introduction of colors is an first step learning for early childhood, where when a child knows the colors, it will be easier for children to learn other things, such as learning shapes, names of objects, animals and other learning [1]. Based on the results of research conducted by the University of British Columbia, certain colors can help concentration, attention span and hence facilitate memory retention and learning In that research, it was also concluded that the colors red and blue were the best for improving brain function and cognitive skills, where red was much better than blue as far as detail oriented tasks, and memory retention were concerned by as much as 31\%. [1], [2].

The ability to identify colors is part of cognitive abilities, where the ability to recognize colors is very important for children's brain development because color recognition can stimulate children's sense of sight [3], [4]. In addition to stimulating the child's sense of sight, identify colors can also increase children's creativity and thinking power to remember [5]. Some colors can also be used to enhance learning and affect mood, for example yellow can create positive feelings, to maintain attention and encourage 
creativity. Beside that, there are orange colors to encourage creativity, and there are also green and purple colors to create serenity [6], [7]. From the description that has been submitted, it can be concluded that if a child learns colors or knows colors before the child learns other things, it will making learning process more faster, rather than if the child learns other things before getting know the colors [3], [8].

In this research, observations were made on June 16, 2021 to the Generasi Penuai school students, Tangerang Indonesia, with a total students is 25 . From the results of the observations, there are some students that still confused or get difficulty to identify colors through conventional teaching. Conventional methods that applied in the class to introduce the colors for students is by giving Student Worksheets, with that method, students are not given the opportunity to try to explore on their own, so students look not too enthusiastic and look bored to learning the color tasks that given by the teacher.

From the observations in that class, also showing that most students were still confused in identify colors, mentioning colors, recognizing color patterns, showing colors and giving color samples. The factors that can affect the ability to identify colors can be caused by two factors, namely internal factors and external factors. While cognitive development in identify colors can be influenced by talents and interests. Given that cognitive development is the basis for forming children's thinking styles to obtain a real concept [9], [10]. Therefore, in introducing color to early childhood, need to applied the right method in accordance with characteristics of students and learning material.

In learning activities that use the experimental method, students are given the opportunity to get experience themselves or do it themselves, follow the process, observe objects, analyze, prove and draw conclusions about a problem related to the material provided [6], [11]. By choosing appropriate technologies such as interactive learning applications using mobile devices and multitouch displays, preschool children can easily master it and understand learning content, because touch screen technology offers interactive experience modes that reflect the nature of children and make learning more effective [12]. So the experimental method with interactive learning application is considered very appropriate to be applied to early childhood or preschool children to introduce the colors.

Based on the above background, this research aims to measure the effectiveness of using color learning applications based on mobile platform as an alternative learaning to identify color and to measure the level of user acceptance of the color learning application that has been made. With the hope of benefits that the learning can be done with a fun way, because with the fun way, that will make children learn faster and more easily understand the contents of the learning.

\section{Methodology}

This research uses a quasi-experimental type, this type of experimental research is using to see the effectiveness in one group by applying a certain treatment to another under controlled conditions [13]. The treatment that used in this research is using an interactive color recognition application that has been made based on the problems that 
have been described previously. And the data collection technique using an oral test to measure the ability to recognize colors in early childhood responden [14]. The form of testing in this study, used the Pretest and Posttest One Group Design testing with the "paired sample $t$ test" method. And for data analytic technique that used is the paired sample test with a significance level of 5\% [15]. Also will do acceptance testing for the color recognition application that has been built using a user acceptance test [16].

The subjects in this research is student Generasi Penuai Kindergarten School, Tangerang Indonesia, with a total of 25 students, and it was conducted online using the Zoom platform. This research was conducted from June to November 2021. In this research, there were two meetings, where the first meeting was for the introduction of basic colors and then a pretest was carried out, after that the students were also given an introduction to the interactive multimedia application of color recognition that had been built and how to use it. The distance from the first meeting to the second meeting is one week. At the second meeting, the color recognition Posttest will be tested for all students.

For application development to the evaluation stage in this research using ADDIE development model, where the stages in developing interactive learning applications go through several stages, namely: Analyze, Design, Development, Implementatiton, and Evaluation [17], [18]. In analyze step, the components that needed for the design and development stages of color recognition applications for preschoolers are determined based on the results of the problem observations that have been carried out. In design step, application mockup is created and the application content is designed based on the problems that occur. In development step, do implemented designs that have been made to develop application. At the implementation step, testing was carried out with qualitative methods with the help from experts and also tested with quantitative methods with the help of responden. At the evaluation stage, an application evaluation that has been made based on suggestions from experts and respondents is carried out.

Interactive media applications for early childhood that have been developed are expected to play an important role in early childhood learning, because the selection of the right media will make learning more optimal [9], [19]. The application developed in the form of interactive multimedia resembles a game with color recognition material for children and is based on Android. A child who uses the application will learn colors by carrying out simple practicums from identify colors, choosing colors, shooting colors, guessing colors in shapes, counting colors and spelling colors. 


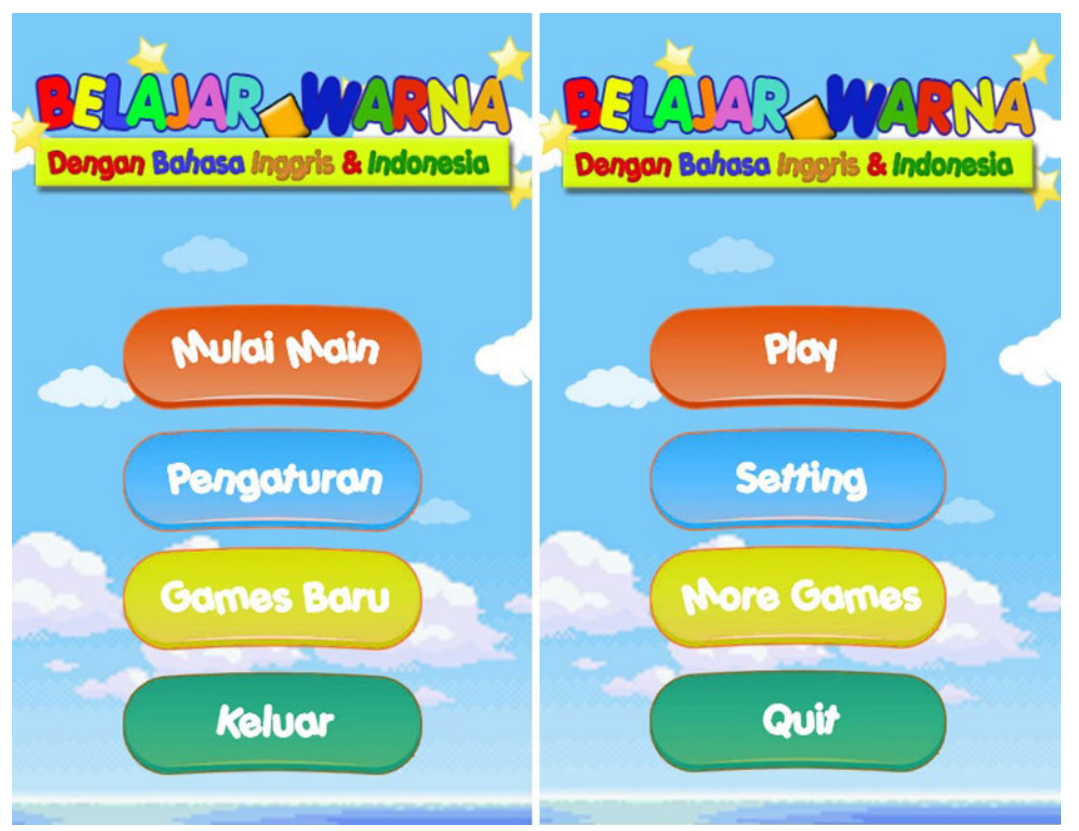

Fig. 1. Main menu application in Indonesian and English language

On the main screen of the application as shown in Figure 1, the user interface is made as attractive as possible by choosing bright colors as an initial impression to attract the interest of preschool students. In the main menu, two language facilities are also provided, namely in Indonesian and English language, so that user can choose the language to be used. When the user choice the language on this menu, the language will also affect all the content in the application. By default, the selected Language option is in Indonesian language. 


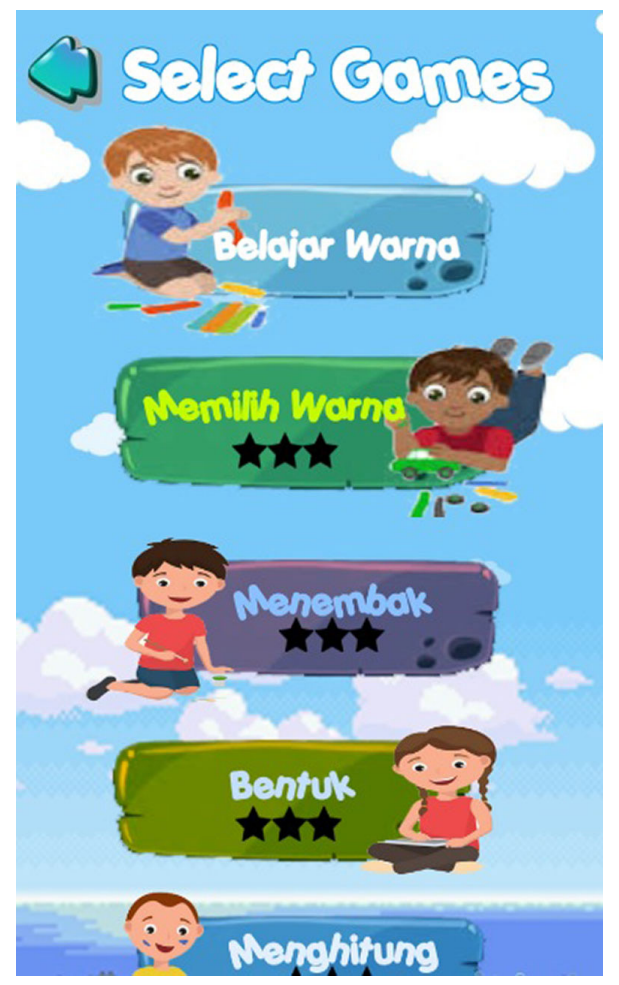

Fig. 2. Select menu for choosing learning color content

After selecting the "Mulai Main" or "Play" button user will be given a choice of interactive learning menus, to select what is content learning that they want to try. Select menu is shown in Figure 2. There are six color learning menus provided, such as, identify colors, choosing colors, shooting colors, guessing colors in shapes, counting colors and spelling colors.

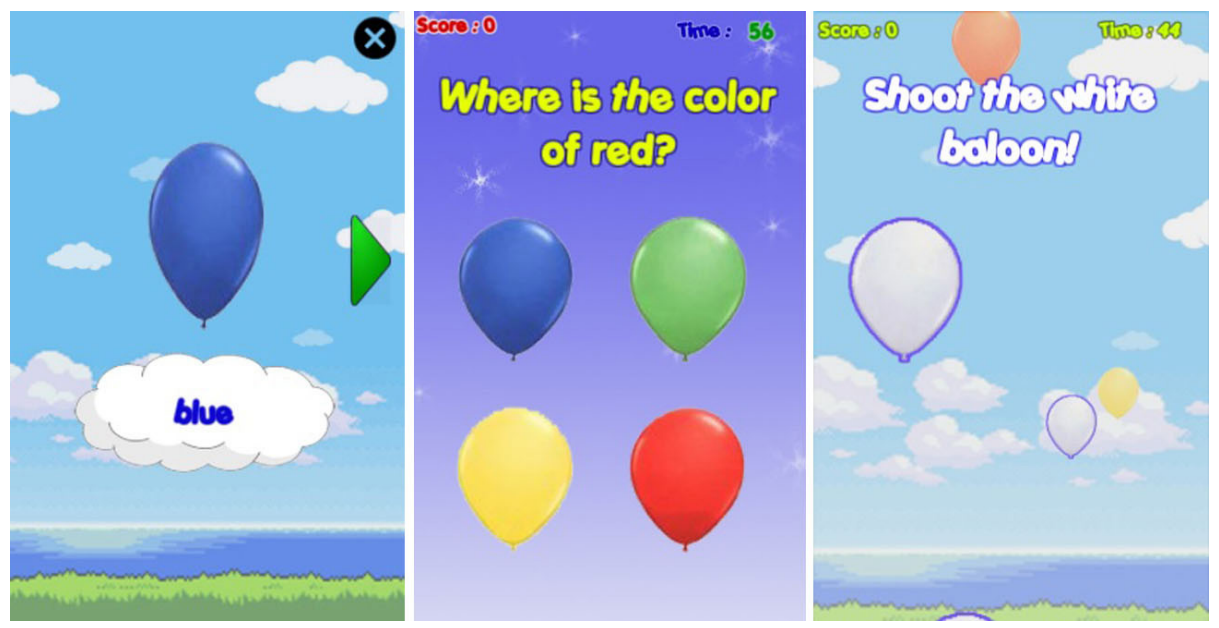

Fig. 3. Content learning identify color, choosing color and shooting color 
In the first interactive learning menu, identify color, in this learning content that shown in Figure 3 is equipped with sound and letters and also examples of colorful balloon images. In the second interactive learning, choosing colors, interactive learning in the application is in the form of multiple choice, where user need to choose the right color baloon according to the questions that appear. For the third color recognition interactive learning, shooting color, interactive learning in the form of a flying color baloon, and the user need to shoot or choosing the color baloon as fast as posible before the baloon is gone, according to the questions that appear.
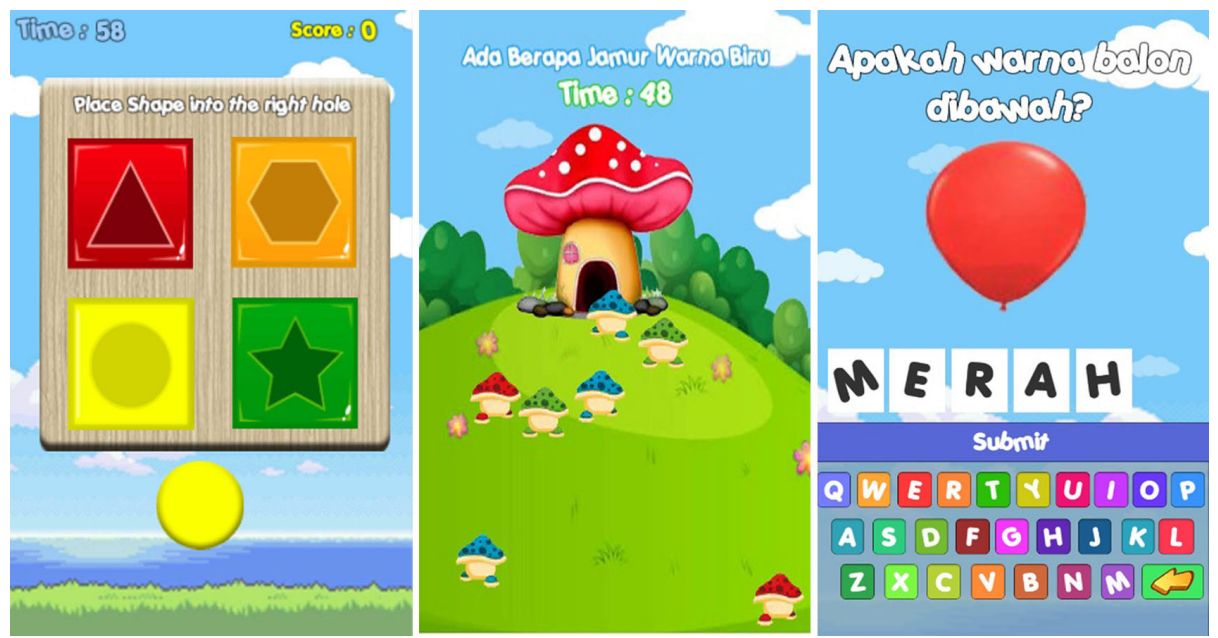

Fig. 4. Content learaning guessing colors in shapes, counting colors and spelling colors

In the fourth interactive learning menu that shown in Figure 4, guessing colors in shapes, interactive learning is in the form of putting colored shapes into the appropriate holes. In the fifth interactive learning, counting colors, interactive learning is in the form of walking mushrooms, where the users are need to count the number of color mushrooms according to the questions that appear. And in the last interactive learning, spelling colors, interactive learning is in the form of practice to write name of colors according to the color balloons that appear.

\section{$3 \quad$ Result}

After completing the application development and pretest posttest testing with the "paired sample t test" method for the Generasi Penuai school students, Tangerang Indonesia, which was carried out online, with a total of 25 students, the results of the pretest and posttest obtained as shown in Table 1. 
Table 1. The results of the pretest and posttest of the ability to identify colors using the "paired sample t test" method

\begin{tabular}{|l|c|c|c|}
\hline \multicolumn{1}{|c|}{ Description } & Pretest & Posttest & Difference \\
\hline Total Score & 1366 & 2034 & 668 \\
\hline Mean & 54.64 & 81.36 & 26.72 \\
\hline Std. Deviation $\left(\mathrm{S}_{\mathrm{d}}\right)$ & 9.11 & 10.60 & 16.021548 \\
\hline Min Score & 40 & 66 & 6 \\
\hline Max Score & 75 & 96 & 56 \\
\hline t-stat & - & - & 8.69 \\
\hline
\end{tabular}

From Table 1 it can be seen that the increase in the results of the magnitude t-stat is quite large, which is 8.69 , which proves that there is a significant improvement before and after the pretest and posttest of using the color learning application. So it can be concluded that by giving treatment using a color recognition application, it can improve the ability to recognize colors for early childhood who attend school in the Generasi Penuai, Tangerang, Indonesia.

At the end of the second meeting, a response questionnaire was also distributed to all students who had tried the color recognition learning application. The test was carried out by interviewing children accompanied by their parents or guardians. And in Table 2 you can see the results of the percentage of children's response questionnaires after using an Android-based color recognition learning application using the User Acceptance Test.

Table 2. Table questioner using user acceptance test

\begin{tabular}{|c|c|c|c|c|c|c|}
\hline \multirow{2}{*}{$\mathbf{Q}$} & \multirow{2}{*}{ Question } & \multicolumn{5}{|c|}{ Percentage } \\
\hline & & $\mathbf{A}$ & B & C & D & $\mathbf{E}$ \\
\hline Q1 & $\begin{array}{l}\text { The application color learning has an } \\
\text { attractive user interface. }\end{array}$ & $20 \%$ & $72 \%$ & $8 \%$ & $0 \%$ & $0 \%$ \\
\hline Q2 & $\begin{array}{l}\text { By using the application color learning, } \\
\text { helps me in understanding color names } \\
\text { collection }\end{array}$ & $44 \%$ & $56 \%$ & $0 \%$ & $0 \%$ & $0 \%$ \\
\hline Q3 & $\begin{array}{l}\text { By using the application color learning, } \\
\text { helps me in understanding and identify } \\
\text { color name }\end{array}$ & $52 \%$ & $44 \%$ & $4 \%$ & $0 \%$ & $0 \%$ \\
\hline Q4 & $\begin{array}{l}\text { By using the application color learning, } \\
\text { helps me in spelling color name }\end{array}$ & $48 \%$ & $52 \%$ & $0 \%$ & $0 \%$ & $0 \%$ \\
\hline Q5 & $\begin{array}{l}\text { After using the application color } \\
\text { learning, I became more understanding } \\
\text { color in English and Indonesian } \\
\text { language }\end{array}$ & $28 \%$ & $60 \%$ & $12 \%$ & $0 \%$ & $0 \%$ \\
\hline
\end{tabular}

From the survey results that obtained from Table 2, the grade A refer strongly agree with the Question statement, the grade B refer Agree, grade C refer Neutral, grade D refer Disagree and grade E refer strongly disagree, and with using the Slovin technique, 
with an error margin of eight percent, the recapitulation table can be made to obtain the final results of the questionnaire distributed to the players, as described in Table 3 below.

Table 3. User acceptance test recapitulation

\begin{tabular}{|c|c|c|c|c|c|c|c|c|}
\hline \multirow{2}{*}{$\mathbf{Q}$} & \multicolumn{5}{|c|}{ Score } & \multirow{2}{*}{ Total } & \multirow{2}{*}{$\begin{array}{c}\text { Analysis } \\
\text { (Total / Rpd) }\end{array}$} & \multirow{2}{*}{$\begin{array}{c}\text { Percentage } \\
\text { (Analyis / Qn) } \\
* 100\end{array}$} \\
\hline & 5 & 4 & 3 & 2 & 1 & & & \\
\hline Q1 & 25 & 72 & 6 & 0 & 0 & 103 & 4,12 & 82 \\
\hline Q2 & 55 & 56 & 0 & 0 & 0 & 111 & 4,44 & 89 \\
\hline Q3 & 65 & 44 & 3 & 0 & 0 & 112 & 4,48 & 90 \\
\hline Q4 & 60 & 52 & 0 & 0 & 0 & 112 & 4,48 & 90 \\
\hline Q5 & 35 & 60 & 9 & 0 & 0 & 104 & 4,16 & 83 \\
\hline
\end{tabular}

From table recapitulation that shown in Table 3, total percentage analysis divided by total Question (Qn) is 434, and the average is $86.72 \%$. From the percentage total that got, it can be conclude that, user agrees by using a mobile application to learning color can help students to more easily understand and identify color names.

Beside distributing response questionnaires to children, interviews were also conducted to the teachers of the Generasi Penuai, to know the responses of classroom teachers after implement the research method, is there any improving children's learning before and after using color recognition applications. Based on the results of the interview, the teacher said that our method was new in introducing color to children. The new method provides a positive effect for children, because children become more active when learning, because the activities in learning application wrapped in games, that make children more happy to explore.

\section{Conclusion}

Based on the results of research and analysis using Android-based color recognition applications that have been tested for Kindergarten-level in Generasi Penuai with the pretest and posttest "paired sample t test" method, it was found that there was good development after students using color recognition applications, with the results shown t-stat of 8.69. Beside that, the results of user acceptance test for the applications that were built were also quite good, namely $86.72 \%$. Also the results of interviews from class teachers showed positive results for the method used in the class, because there was a positive effect for students, that make students were more happy to learn by using the color recognition application that was built. 


\section{$5 \quad$ Acknowledgment}

Thank you to the Universitas Multimedia Nusantara campus which is located at Jl. Scientia Boulevard, Curug Sangereng, Kec. clp. Dua, Tangerang, Banten 15810, Indonesia which has become a place for researchers to develop this journal research. Hopefully, this research can make a major contribution to the advancement of technology in Indonesia.

\section{References}

[1] S. Kurt and K. K. Osueke, "The Effects of Color on the Moods of College Students," SAGE Open, vol. 4, no. 1, p. 215824401452542, 2014. https://doi.org/10.1177/2158244014525423

[2] Black lights, "Quick Answer: What Color Helps Memorize?" https://mississaugaautoloan.com/, 2021. [Online]. Available: https://mississaugaautoloan.com/qa/what-color-helps-memorize.html. [Accessed: 19-May-2021].

[3] F. Duyan and R. Ünver, "A Research on the Effect of Classroom Wall Colours on Student's Attention," A/Z ITU Journal of the Faculty of Architecture, vol. 13, no. 2, pp. 73-78, 2016. https://doi.org/10.5505/itujfa.2016.57441

[4] B. Chang et al., "New Prairie Press The Impact of Colors on Learning," Roeper Review, vol. 7, no. 4, pp. 0-6, 2018.

[5] M. A. Dzulkifli and M. F. Mustafar, "The Influence of Colour on Memory Performance: A Review," The Malaysian Journal of Medical Sciences: MJMS, vol. 20, no. 2, pp. 3-9, 2013.

[6] R. Kumi, C. M. Conway, M. Limayem, and S. Goyal, "Research Article Learning in Color: How Color and Affect Influence Learning Outcomes," IEEE Transactions on Professional Communication, vol. 56, no. 1, pp. 2-15, 2013. https://doi.org/10.1109/TPC.2012.2208390

[7] O. Olurinola and O. Tayo, "Colour in Learning: It's Effect on the Retention Rate of Graduate Students," Journal of Education and Practice, vol. 6, no. 14, pp. 1-6, 2015.

[8] M. Hill, Young Children and Their Perceptions of Colour: An Exploratory Study. 2011.

[9] A. J. Elliot, "Color and Psychological Functioning: A Review of Theoretical and Empirical Work," Frontiers in Psychology, vol. 6, no. APR, pp. 1-8, 2015. https://doi.org/10.3389/ fpsyg. 2015.00368

[10] N. A. Jalil, R. M. Yunus, and N. S. Said, "Environmental Colour Impact upon Human Behaviour: A Review," Procedia-Social and Behavioral Sciences, vol. 35, no. December 2011, pp. 54-62, 2012. https://doi.org/10.1016/j.sbspro.2012.02.062

[11] W. Istiono, "Education Games To Learn Basic Algorithm With Near Isometric Projection Method," International Journal of Advanced Studies in Computer Science \& Engineering, vol. 8, no. 7, pp. 6-10, 2019.

[12] S. Papadakis, "Advances in Mobile Learning Educational Research (A.M.L.E.R.): Mobile Learning as an Educational Reform," Advances in Mobile Learning Educational Research, vol. 1, no. 1, pp. 1-4, 2021. https://doi.org/10.25082/AMLER.2021.01.001

[13] M. Gopalan, K. Rosinger, and J. Bin Ahn, "Use of Quasi-Experimental Research Designs in Education Research: Growth, Promise, and Challenges," Review of Research in Education, vol. 44, no. 1, pp. 218-243, 2020. https://doi.org/10.3102/0091732X20903302

[14] R. D. Palacio, P. J. Negret, J. Velásquez-Tibatá, and A. P. Jacobson, "Paired Oral Tests: A Literature Review," A Journal on Language and Language Teaching, vol. 21, no. June, pp. 105-110, 1967. https://doi.org/10.24071/11t.2018.Suppl2110 
[15] D. W. Zimmerman, "A Note on Interpretation of the Paired-Samples t Test," Journal of Educational and Behavioral Statistics, vol. 22, no. 3, pp. 349-360, 1997. https://doi. org/10.3102/10769986022003349

[16] H. K. N. Leung and P. W. L. Wong, “A Study of User Acceptance Tests,” Software Quality Journal, vol. 6, no. 2, pp. 137-149, 1997. https://doi.org/10.1023/A:1018503800709

[17] C. Thim-Mabrey, "Sprachwandel in übersetzungsbearbeitungen zwischen 1846 und 1999," Neuphilologische Mitteilungen, vol. 107, no. 3, pp. 361-373, 2006.

[18] E. Widyastuti and Susiana, "Using the ADDIE Model to Develop Learning Material for Actuarial Mathematics," Journal of Physics: Conference Series, vol. 1188, no. 1, 2019. https://doi.org/10.1088/1742-6596/1188/1/012052

[19] Fedro and W. Istiono, "Mandarin Language Learning with Gamification Method," International Journal of Advanced Trends in Computer Science and Engineering, vol. 10, no. 5, pp. 3046-3052, 2021. https://doi.org/10.30534/ijatcse/2021/171052021

\section{Author}

Wirawan Istiono is currently a lecturer and researcher in Universitas Multimedia Nusantara and also serving as the head coordinator of the Game Development Laboratory. His research interests include requirements engineering in software application development, computer engineering, and human computer interaction (email: wirawan. istiono@umn.ac.id).

Article submitted 2021-11-16. Resubmitted 2022-01-05. Final acceptance 2022-01-05. Final version published as submitted by the authors. 


iJIM - Vol. 16, No 05, 2022

\section{Imprint}

iJIM - International Journal of Interactive Mobile Technologies

http://www.i-jim.org

\section{Editor-in-Chief}

Stamatios Papadakis, University of Crete, Greece

\section{Senior Editor-in-Chief}

Thrasyvoulos Tsiatsos, Aristotle University of Thessaloniki, Greece

\section{Executive Editor}

Michael E. Auer, CTI Frankfurt/Main - New York - Vienna - Bangalore

\section{Section Editors}

Apostolos Gkamas, University Ecclesiastical Academy of Vella, loannina, Greece Micaela Dinis Esteves, Polytechnic Institute of Leiria, Portugal

\section{Technical Editor}

Sebastian Schreiter, Lagorce, France

\section{Editorial Board}

A. Y. Al-Zoubi, Princess Sumaya University for Technology Amman, Jordan Yacob Astatke, Morgan State University, Baltimore, MD, USA

Stephan Böhm, RheinMain University of Applied Sciences, Germany Daphne Economou, University of Westminster, United Kingdom Juan Antonio Guerrero-Ibáñez, University of Colima, Mexico Hyo-Joo Han, Georgia Gwinnett College, Lawrenceville, GA, USA Markus Feisst, University of Nottingham, UK

Ferial Khaddage, Deakin University, Australia Kinshuk, Athabasca University, Canada

Adamantios Koumpis, Berner Fachhochschule, Switzerland Tzu-Chien Liu, National Central University, Taiwan Hiroaki Ogata, Tokushima University, Japan Andreas Pester, British University in Egypt, Egypt Raul Aquino Santos, University of Colima, Mexico Ana Serrano Tellería, University of Castilla La Mancha, Spain Doru Ursutiu, University Transilvania of Brasov, Romania Mudasser Fraz Wyne, National University, Kearny Mesa, CA, USA

\section{Indexing}

International Journal of Interactive Mobile Technologies is indexed in Elsevier Scopus, INSPEC, Ulrich, DOAJ, EBSCO, Google Scholar, and DBLP

\section{Publication Frequency}

Bimonthly

\section{Publisher}

International Association of Online Engineering (IAOE)

Kirchengasse 10/200

A-1070 WIEN

Austria 